\title{
Ability of basic school teachers in developing 2013 curriculum based learning administration devices in elementary school
}

\author{
Yoseu Anggaraenir ${ }^{1}$, Happy Fitria ${ }^{2}$, Achmad Wahidy ${ }^{3}$ \\ ${ }^{1}$ Sekolah Dasar Negeri 7 Air Kumbang, Indonesia \\ ${ }^{2}$ Universitas PGRI Palembang, Indonesia
}

\section{Article Info \\ Article history: \\ Received Jul 23 ${ }^{\text {th }}, 2021$ \\ Revised Aug $11^{\text {th }}, 2021$ \\ Accepted Aug 30, 2021}

\section{Keyword:}

Learning Tools

K-13 Curriculum

\begin{abstract}
This study aims to determine and describe the ability of elementary school teachers in preparing the 2013 curriculum-based learning administration tool in SD Negeri 3 Air Kumbang sub-district. This type of research is descriptive qualitative research. Data collection tools use documentation, interviews, observation and literature review. The data analysis technique used qualitative descriptive analysis techniques which consisted of data collection, data reduction, data presentation, and conclusion and verification. The results of this study indicate that the teacher's ability to arrange learning administration tools in SD Negeri 3 Air Kumbang District, which is carried out through the process, strategic planning, strategy implementation and strategy evaluation have been going according to what was expected from the start so that there is the ability of the teacher to compile this school administration tool. then it can help in improving the quality of learning at SD Negeri 3 Air Kumbang District. It remains only to how the teacher and all school members maintain the quality of learning that has been obtained by SD Negeri 3 Air Kumbang District.
\end{abstract}

(C) 2021 The Authors. Published by IICET.

This is an open access article under the CC BY-NC-SA license (https://creativecommons.org/licenses/by-nc-sa/4.0

\section{Corresponding Author:}

Anggaraenir, Y.,

Sekolah Dasar Negeri 7 Air Kumbang, Indonesia

Email: yoseuanggaraenir567@gmail.com

\section{Introduction}

One of the success of education can be measured by the extent of student learning achievement. Low student achievement indicates the low quality of educational institutions. Thus it is necessary to have maximum efforts from all components of education to improve the quality of learning in educational institutions. [1] stated that efforts to improve the quality of learning in educational institutions were carried out by increasing the ability of teachers. Townsend and Butterworth, several things that determine the realization of a quality education process, including the active participation and sense of responsibility of teachers.

From the above opinion, it is known that one of the important components in efforts to improve the quality of learning is the maximum participation of the teacher. Teacher professionalism is one of the dominant factors that contribute to maximum student achievement. [2] with the research results stated that teachers can contribute to increasing learning achievement able to be active role models, innovative creatives and have high integrity in school.

Therefore, it takes teachers who have the competence to carry out their core duties, namely managing learning, as stated [3] arguing that in order for someone to have the right skills and quality, he must meet two 
main requirements. First, knowing and understanding what the job wants. Second, the desire to do the job properly and with quality. When it is related to the teaching profession, the first requirement is that the teacher must know and understand what the profession as a teacher wants. The second requirement is that teachers must have the desire to carry out their profession as well as possible.

In managing learning, teachers have duties and responsibilities, both administrative and functional. The success of teachers in carrying out learning activities does not only require the ability to master subject matter, teaching strategies and methods, using media or learning tools. But the teacher must be able to provide or create conducive and pleasant learning situations andconditions that can be realized if the teacher I $\backslash s$ able to regulate the learning atmosphere, condition students to learn and take advantage of learning facilities or media and can control a pleasant atmosphere to achieve learning goals.

The results of the research above, explain that the importance of the learning planning process in an effort to realize a good and effective quality of learning, and learning planning is part of the learning administration that must be implemented by the teacher. The teacher's ability to carry out teaching administration greatly affects the creation of an effective learning process. Therefore, teachers as the spearhead in the educational process who are directly involved in the teaching and learning process must be able to carry out learning administration. It is hoped that with the implementation of good learning administration, the teaching and learning process will run with what is expected in accordance with educational goals.

Learning administration includes an annual program, a semester program, a syllabus, a lesson plan, evaluation and remedial is a concept or plan of a teacher in transferring knowledge to students systematically. Without a plan and standards in teaching, the teaching materials given to students will not be conveyed systematically [4]. Therefore, a teacher must be able to carry out learning administration well.

However, in reality there are still many teachers who do not realize the importance of carrying out the learning administration. In other words, learning administration is considered only for formality, and the material to be delivered is considered easy and very memorized so that learning does not need to be administered. In fact, to improve the quality of education, teachers must carry out learning administration as well as possible. Through the preparation of learning administration, the quality of the education and learning process can be aligned with existing process standards. Process standards, as stated in the article Government Regulation Number 19 of 2005 concerning National Education Standards, process standards are national education standards related to the implementation of learning in educational units to achieve graduate competence, process standards contain minimum criteria for the learning process in basic education units and medium in the entire jurisdiction of the Republic of Indonesia.

This standard process applies to primary and secondary education in the formal pathway, both in the package system and on the semester credit system. Therefore all school stakeholders, especially school principals, have a major role in the effort to apply the 2013 curriculum to improve the quality of learning in schools. As stated [5] the quality of education received in schools will produce quality learning as a product of the effectiveness of the principal's leadership.

Then the [6] curriculum is relevant. [2] stated that efforts to improve the quality of learning in educational institutions were carried out by increasing teacher participation. Teachers who are in direct contact with the learning process must always try to improve their ability to plan 2013 curriculum-based learning, one of which is by increasing the ability to organize learning administration. Considering the position of the teacher is very strategic in determining success.

The teacher is also a figure who will determine the depth and breadth of the subject matter, determine the evaluation tools and learning resources that will be presented in front of the class. This task is outlined in learning tools in the form of a syllabus and a lesson plan. The ability of teachers to plan, create and implement learning cannot be separated from the guidance of school principals in guiding and directing special teachers in the academic field.

This research was conducted at SD Negeri 3 Air Kumbang. Researchers chose SD Negeri 3 Air Kumbang with the consideration that the SD had used the 2013 curriculum in the learning process. In addition, this SD is a public school that has advantages when viewed from the achievements it has achieved. SD Negeri 3 Air Kumbang, which currently has the status of accresditation B, has adequate resources and facilities and infrastructure as well as a strategic and easy-to-reach school location.Based on the results of preliminary observations made by researchers on May 19, 2020 to May 23, 2020, researchers found an indicator stating that SD Negeri 3 Air Kumbang teachers were not able to apply the 2013 curriculum to the overall learning process. The results of the researchers' preliminary observations, the researcher found indicators of the 
implementation of learning administration which showed that there were still teachers who had not made the completeness of the learning administration as they should because the teacher was busy.

Teacher learning administration is one of the teacher's duties in the teaching and learning process. The administration sector supports the teaching and learning process in the context of implementing education. It is impossible to implement education if there is no administrative support [11].The teacher's duties in the teaching and learning process include pedagogical duties and administrative duties. When viewed from the aspect of terminology, teacher learning administration consists of 3 words, namely administration, learning, and teacher. Administration according to [7] is an effort to achieve goals effectively and efficiently by utilizing people in a collaborative pattern.

Operational quality of learning can be interpreted as the intensity of systemic and synergistic linkages between teachers, students, learning climate, and learning media in producing optimal learning processes and outcomes in accordance with curricular demands [8]. [9], the quality of learning is a level of achievement of the initial learning objectives including art learning, in achieving these goals in the form of increasing knowledge, skills and developing attitudes of students through the learning process in class.

\section{Method}

This research was conducted at SD Negeri 3 Air Kumbang. The research was conducted from September 2020 to January 2021. This research used descriptive qualitative methods. Data collection techniques in this study using observation, interview and documentation techniques. This is based on the opinion of [10] the success of a naturalistic research is very dependent on the accuracy and completeness of notes compiled through observation, interviews, documentation and literature study. [11] argues that qualitative data analysis is an effort made with data, organizing data, sorting it into manageable units, synthesizing it, looking for and finding patterns, finding what is important and what is learned, and what can be told to others. The data analysis techniques used in this study included data reduction, data presentation and conclusion drawing. The data validity test was carried out in two stages, namely the Credibility Test which is a test of confidence in the research data and the dependability test is a reliability test. A reliable study is if other people can repeat / replicate the research process [12].

\section{Results and Discussions}

Based on the results of the research, it can be argued that the teacher's ability to carry out learning activities, especially in preparing the administration of learning tools and the implementation of 2013 curriculum-based learning in good categories based on the results of research which states that the ability to prepare Learning Implementation Plans, prepare administrative tools for implementing learning and learning evaluation in the good enough where SD Negeri 3 Air Kumbang teachers were able to insert components of lesson plans, worksheets, and assessment instruments.

Good, it means that the educator is able to prepare learning tools, but only partly in accordance with the provisions of the formulation of the lesson plan components, worksheets, and assessment instruments. Enough, means that the educator is only able to prepare learning tools but not in accordance with the provisions of the formulation of the lesson plan components, worksheets, and assessment instruments. This does not mean that the educator is completely incapable of preparing learning tools in accordance with the provisions of the lesson plan component formulation, worksheets, and assessment instruments. Based on the description of the research data, it shows that the implementation of the ability of educators to prepare learning tools as a whole is in the sufficient category.

The teachers at SD Negeri 3 Air Kumbang generally already know the purpose of the preparation of the learning tools themselves. The teachers said that the learning tools arranged were of course very useful in supporting the learning process, because they served as a teacher's direction, reference and control to carry out the learning process. With the existence of learning devices, it is hoped that learning activities can be systematically designed and make it easier for teachers to carry out learning. The teacher's opinion is supported by the opinion expressed by [13] which explains that basically learning devices have a function to make it easier for teachers to implement or manage learning activities in the classroom.

The learning tools prepared by the teacher include syllabus and lesson plans,There are several problems faced by teachers in the preparation of learning tools including problems for teachers who do not compile lesson plans independently. This means that teachers do not independently compile lesson plans, as stated by [7] many teachers take shortcuts by not making preparations when they want to do lessons, so that teachers 
teach without preparation. In addition, related to the preparation of learning tools, especially lesson plans, teachers have difficulty determining the allocation of learning time, formulating competency achievement indicators and determining learning methods in the lesson plans.

The teacher in compiling the assessment has not yet reached the stage of analyzing items for each problem. Other than that, After conducting the assessment, the teacher rarely performs analyzes such as analyzing student learning outcomes by seeing how many students have completed, analyzing the most difficult questions. This is in accordance with the opinion expressed by [14] "almost all teachers do not analyze the learning outcomes that have been done.Teachers in preparing teacher assessments also experience problems in the preparation of various forms of evaluation questions. In compiling the items, there were teachers who rarely composed multiple choice questions, usually only arranging questions in a short form and description.

The problems experienced by these teachers are the same as those expressed by [14] that most teachers make questions consisting of only short questions or descriptions without any multiple choice questions. The initial activity carried out in assessing the ability of teachers in compiling instructional administration is to formulate supervision activities to follow up on the results of administrative supervision of teacher learning devices. Then the principal conducts some preliminary studies as material before supervising teachers. thus the principal and a team that has been formed consisting of 2 teachers have prepared a program of supervision activities before implementation. This is intended so that the implementation can run according to what is expected. As for the programs arranged regarding the schedule of activities consisting of a schedule from implementation to the end, the necessary instruments, the objectives to be achieved, a design to improve teacher performance,

The above statement is supported by the results of research conducted by Ajasan (with the results of the research being found that: Assessment of the teacher's ability to arrange the administration of the principal's learning tools is prepared referring to the identification of problems faced by teachers based on the results of previous year's supervision such as assessment, coaching and helping teachers' difficulties, and SWOT analysis, then poured into the Academic Supervision Plan program according to teacher needs; The implementation of administrative supervision of teacher learning devices by the principal is carried out in three stages, namely: initial survey before supervising the administration of teacher learning devices, class visits to find out the course of learning, and reviewing the results of class visits and providing appropriate solutions in overcoming problems faced by teachers; and Evaluation of the implementation of administrative supervision of teacher learning devices by the principal, including evaluation of job descriptions and evaluation of documentary evidence, by looking directly at the evidence of assignments that have been carried out by the teacher then providing input if there are errors or deficiencies.

It is expected that the principal can direct and supervise teacher performance, especially through the program, implementation and evaluation of supervision effectively and efficiently, so that student achievement can be improved. by looking directly at the evidence of assignments that have been carried out by the teacher then providing input if there are errors or deficiencies. It is expected that the principal can direct and supervise teacher performance, especially through the program, implementation and evaluation of supervision effectively and efficiently, so that student achievement can be improved. by looking directly at the evidence of assignments that have been carried out by the teacher then providing input if there are errors or deficiencies. It is expected that the principal can direct and supervise teacher performance, especially through the program, implementation and evaluation of supervision effectively and efficiently, so that student achievement can be improved.

The school principal plans to implement administrative supervision of teacher learning devices for teachers twice a year, namely once in the odd semester and once in the even semester for follow-up programs from the results of previous supervision. The implementation of administrative supervision of teacher learning tools carried out by the principal is also designed in a kinship and not coercion. The school principal holds a meeting before implementing supervision and the principal also allows the teacher to provide input so that supervision activities can run well. this makes the teacher not feel burdened by the assessment of the teacher's ability to administer the learning tools.

Thus, the implementation of supervision carried out by the principal is by means of humanistic techniques, not finding fault, but really helping teachers to be able to work better and be focused in carrying out their duties. The supervision techniques that are often used in the implementation of supervision in SD Negeri 3 Air Kumbang District are class visit techniques, individual talks, discussions about problems faced by teachers relating to the implementation of teaching and learning. The school principal also prepares a supervision instrument that has been formulated by the principal and the team that assists in the supervision activity. with this instrument, the implementation of class visits runs more effectively to observe teachers working, 
From the results of the visit, the principal then gave an assessment in the form of the highest and lowest scores that had been determined as well as notes on what notes needed to be corrected by the teacher. After the class visit activities carried out by the principal and the principal have received the results of the assessment, then the next activity is to supervise the practice of teacher assessment of students to improve school performance.

The results of this study are supported by research conducted [15] the results showing that the administrative supervision planning for teacher learning devices is prepared at the beginning of the new academic year by involving the vice principal and teachers. The target in the planning of administrative supervision of the principal teacher's learning device is the teacher's ability to manage learning, starting from planning, implementing, and evaluating student learning outcomes. The implementation of administrative supervision of teacher learning devices is carried out in advance by communicating to teachers, carried out twice in one semester, or four times in one school year. Administrative supervision techniques for teacher learning devices used are class visits, teacher meetings.

\section{Conclusions}

From the results of research and discussion, the following conclusions can be drawn. The assessment of learning administration tools at SD Negeri 3 Air Kumbang is carried out through academic supervision which includes the planning, implementation, evaluation and follow-up of the results of supervision of the learning administration equipment. The assessment instrument refers to the learning instrument supervision instrument that has been designed by the principal based on the 2013 curriculum supervision instrument of the Directorate General of Teachers and Education Personnel, Ministry of Education and Culture of the Republic of Indonesia in 2016.teachers of SD Negeri 3 Air Kumbang in carrying out learning activities, especially in preparing the administration of learning tools and implementing 2013 curriculum-based learning based on the results of research which states that the ability to prepare Learning Implementation Plans, preparing administrative tools for implementing learning and learning evaluation is in a fairly good category. Teachers face in the preparation of learning tools, among others: time constraints, teacher's busyness; students' diverse conditions; factors of teaching experience and years of service; teachers find it difficult to operate learning media, limited number of learning environments and media available in schools; space or laboratory constraints.

\section{References}

Usman, H. (2012). Faktor-faktor yang Mempengaruhi Perilaku Kepala Sekolah dalam Jurnal Tenaga Kependidikan, Vol.2, No.3. 12-21.

USDn, H. (2013). Faktor-faktor yang Mempengaruhi Perilaku Kepala Sekolah dalam Jurnal Tenaga Kependidikan, Vol.2, No.3. 12-21.

Arsyad, A. (2011). Media Pembelajaran. Jakarta: PT Raja Grafindo.

Suparlan. (2010). Pendidikan Karakter:Sedemikian Pentingkah,dan Apakah yang Harus Kita Lakukan dalam suparlan.com. http://www.suparlan.com/pages/posts/pendidikan-karakter-sedemikianpentingkah-dan-apayang-harus-kita-lakukan-305.php

Sergiovanni. (2011). The Principalship: AReflective Practice Perspective. Boston:Allyn and Bacon Inc.

Townsend, D \&Butterworth. (2012). Your Child's Scholl. New York: A Plime Book.

Daryanto. (2011). Media Pembelajaran. Bandung: Satu Nusa.

Haryati, T., \& Rochman, N. (2012). Peningkatkan Kualitas Pembelajaran Pendidikan Kewarganegaraan Melalui Praktik Belajar Kewarganegaraan (Project Citizen). CIVIS, 2(2/Juli).

Prasetyo, Z. (2013). Konsep Dasar Pendidikan IPA. Yogyakarta: FMIPA UNY

Fauzan, A. (2012). Metodologi Penelitian kualitatif. JogJakarta: Ar-Ruzz Media

Moleong, L, J. (2011) Metodologi Penelitian Kualitatif, Penerbit PT Remaja Rosdakarya.

Sugiyono. (2011). Metode Penelitian Kuantitatif dan R dan D, Bandung : Alfabeta.

Fathurrohman, M dan Sulistyorini. (2012). Belajar Dan Pembelajaran Meningkatkan Mutu Pembelajaran Sesuai Standar Nasional. Yogyakarta: Teras.

Subini, Nini.2011.Mengatasi Kesulitan Belajar pada Anak. Jogjakarta: Javalitera

Zulfakar, Z., Lian, B., \& Fitria, H. (2020). Implementasi Supervisi administrasi perangkat pembelajaran guru Dalam Meningkatkan Kinerja Guru. JMKSP (Jurnal Manajemen, Kepemimpinan, dan Supervisi Pendidikan), 5(2).230-244. 